\title{
Chronic Treatment with Opiate Agonists in Bulgaria - Assessing the Quality of Life Using SF 36 v. 2
}

\author{
Sava V. Petrov ${ }^{1}$, Maria M. Orbetzova ${ }^{1}$, Yanko T. Iliev² ${ }^{2}$ Doychin T. Boyadzhiev ${ }^{3}$ \\ 1 Second Department of Internal Diseases, Section of Endocrinology, Faculty of Medicine, Medical University of Plovdiv, Plovdiv, \\ Bulgaria \\ 2 Department of Pharmacology and Drug Toxicology, Faculty of Pharmacy, Medical University of Plovdiv, Plovdiv, Bulgaria \\ ${ }^{3}$ Department of Applied Mathematics, University of Plovdiv, Plovdiv, Bulgaria
}

\author{
Correspondence: Sava Petrov, \\ Second Department of Internal \\ Diseases, Section of Endocrinol- \\ ogy, Faculty of Medicine, Medical \\ University of Plovdiv, Plovdiv, \\ Bulgaria, 15A Vasil Aprilov Blvd., \\ 4002 Plovdiv, BULGARIA \\ E-mail: sava86@abv.bg \\ Tel.: +359878987123
}

Received: 17 November 2015 Accepted: 01 June 2016

Published: 30 June 2016

Key words: methadone, quality of life, opiate, addiction

Citation: Petrov SV, Orbetzova MM, lliev YT, Boyadzhiev DT.

Chronic treatment with opiate agonists in Bulgaria - assessing the quality of life using SF 36 v. 2.

Folia Medica 2016;58(2);115-121, doi: 10.1515/folmed-2016-0019
Introduction: Drug addictions to psychoactive substances are disorders with a complex bio-psycho-social genesis, which are characterized with chronic relapses. Substance addiction causes multifactorial damage to the normal functioning of individuals and requires a multicenter approach for the treatment process.

Aim: The aim of the study was to assess the quality of life of patients undergoing chronic treatment with the opiate agonist methadone using a standardized questionnaire method in Bulgarian.

Material and methods: The study included patients aged 18 to 40 years undergoing chronic treatment with methadone for at least six months. The study included 100 subjects. Seventy-six patients were from 5 clinical programs in Bulgaria; twenty-four clinically healthy age-matched subjects with no history of drug abuse, psychiatric and somatic diseases were the control group.

Results: We found significant differences between patients and controls in all components of the survey $(\mathrm{P}<0.05)$. The patients had lower scores than the control group in the SF-36 in terms of all eight components and both the physical and mental component summaries of the SF-36-survey. Patients compared between the groups by dose, duration of treatment with methadone and period of heroin abuse before initiating treatment did not show significant differences. There were no significant differences between patients with and without hepatitis $C$ virus.

Conclusions: Opiate addiction is a state associated with poor quality of life. The duration of treatment, the methadone dose, period of heroin abuse before initiating treatment and illness of hepatitis $C$ virus does not correlate with lower results.

\section{INTRODUCTION}

Drug addictions to psychoactive substances are disorders with a complex bio-psycho-social genesis. They are characterised with chronic relapses of the disorder. Just like all chronic conditions, their treatment is a long-term process, which may require prolonged and repeated episodes of treatment in order to achieve a stable and sustained remission as well as a lasting recovery. The most commonly used drug for the treatment of opioid dependency in Bulgaria is methadone. It is a synthetic, long-acting agonist of the $\mu$-receptors. It has morphine-like effects such as analgesia, euphoria, sedation, respiratory depression, miosis, bradycardia and physical dependence. The drug was developed in Germany in 1937 by Max Bockmühl and Gustav Ehrhart who worked for the German chemical conglomerate IG Farberindustrie.
They had been studying synthetic ingredients with a structure similar to dolantin - an opioid analgesic agent with similar structure to morphine, which was discovered earlier by the same company. Bockmühl and Ehrhart called their new drug discovery 'Hoechst 10820'. During World War II the chemical formula of 'Hoechst 10820' was distributed worldwide. Initially, methadone was registered in the US in 1947 and used in clinical practice as an analgesic and antitussive drug with the brand names Dolophine and Methadose. Originally the indications for its use were: migraine, dysmenorrhea, chronic pain, neurological pain, advanced cancer or tuberculosis, tetanus and others. Little was known at the time about its pharmacodynamic and pharmacokinetic properties and how it should be prescribed.

Misuse and the wrong prescription of methadone 
led to multiple fatalities. Many deaths of young people were registered in England and Germany from 1940 to 1950 as a result of taking cough medicine containing methadone. ${ }^{1}$

In the modern history of medicine and the correct use of opioids, methadone is mainly used as a tool in maintenance therapy in patients with opioid dependence and less frequently as an analgesic. Chronic methadone maintenance therapy started in the early 1960s in an attempt to counter the emerging epidemic of heroin use and abuse after World War II. In New York, the intravenous use of heroin grew dramatically and by the end of the 1960s it was widely used. ${ }^{2}$ From 1950 to 1961, the death rate from intravenous heroin abuse increased from 7.2 per 10000 to 35.8 per 10000 deaths, and $75 \%$ of the deceased were between 15-35 years of age. During this period the mortality rate of i.v. heroin abuse became the major cause of mortality in New York amongst the younger population. The mean age of heroin related deaths for both sexes was 29 years. In 1989 there were about 1300-1400 registered drug addicts in the National Register of Republic of Bulgaria, with their actual number until 1990 not exceeding 600-800 people. The figure of 1300-1400 people included all people from the beginning of 1980 , using medical opiates such as morphine and Lidol. The peak of drug use was observed after the democratic changes in 1989 and the subsequent liberalisation processes, combined with the destruction of the repressive control apparatus of the country. The reasons for the lack of a drug market in the country before 1990 can only be speculated and could be due to the success of totalitarian control agreements between the Bulgarian secret services and organized crime. $^{3}$ In summarized data from studies in the period from 2010 to 2012 a total of about $560-570$ 000 Bulgarian citizens, in the age range 15 to 64 years, had used some narcotic substance at least once in their lives. Heroin has been the narcotic drug most associated with the problematic use of drugs in Bulgaria for the last 20 years. A survey from 2010 was used to assess 31316 problematic drug substance users in Bulgaria. ${ }^{4}$

The treatment of drug addictions in Bulgaria is based on the principles adopted in the medical standard "Psychiatry". The treatment of addicted patients goes through three main phases:

1. Introduction phase - stabilization of the patient and determining the sustainable supporting individual daily dose of medicine.
2. Phase of rehabilitation and supportive treatment. 3. The final phase - drawing up an individual plan for the completion of treatment and exit from the program, determining the rate of dose reduction and monitoring the medical and psychological condition of the patient. Detoxification is both short and long term. It is used if it is requested by the patient indicated following a medical team assessment or, if necessary, because of treatment discontinuation for other reasons.

Following the implementation of the National Programme for Prevention, Treatment and Rehabilitation of Drug Addiction in the Republic of Bulgaria, a series of methadone maintenance treatment (MMT) programs with opiate agonists and agonists acting as antagonists were launched between 2001 and 2005. ${ }^{5}$ Currently, Bulgaria has thirty registered programs. The total number of patients participating in these groups is 4692. Of these, 4292 receive the methadone treatment, 232 undergo treatment with Substitol and 168 are treated with buprenorphine. The estimation of the average daily dose of methadone is a complex task, which is individually determined for each patient. The average daily dose usually ranges between $80-120$ $\mathrm{mg} /$ day. This amount of methadone should be adequate for:

1. Overcoming the craving for narcotics.

2. Suppression of the opioid withdrawal syndrome for a period of 24-36 hours.

3. Blocking the effect of the administered heroin.

4. Development of tolerance towards euphoria, sedation or other narcotic effects of methadone, which will have a negative impact on the emotional status, perception and capacity of the patient.

5. Developing a tolerance to the analgesic effect of methadone.

It should be noted that some patients need higher doses of methadone. On the other hand, in some patients, the required effects are achieved at lower doses of $60-80 \mathrm{mg} /$ day. The study of GAO (Government Accounting Office) on the effectiveness of methadone programs in the US shows that the minimum effective dose of methadone is $60 \mathrm{mg} /$ day. ${ }^{6}$ A patient adequately maintained on methadone, who is not abusing heroin or other drugs or alcohol, experiences normal emotions and sensitivity for acute and chronic pain. The required methadone dose is determined by the quality and duration of use of heroin, as well as its route of administration.

Chronic methadone maintenance therapy has 
proven effective in reducing the incidence of transmissible infections such as human immunodeficiency virus (HIV) hepatitis B virus (HBV) and hepatitis $\mathrm{C}$ virus (HCV) among intravenous drug users, improving the effectiveness of anti-retroviral treatment for HIV / AIDS and treatment of chronic viral hepatitis. ${ }^{7}$ A reduction in crime rates ${ }^{8}$ and use of illicit drugs ${ }^{9}$ is found in patients undergoing chronic treatment with methadone, as well as improved social integration and family relationships. It has been shown that chronic maintenance treatment with methadone has a positive effect on the quality of life making it better than that at baseline. ${ }^{10-12}$ $\mathrm{HCV}$ is a life-threatening disease and as such it has a great impact on society. ${ }^{13}$ The purpose of this study was to analyze and compare the influence of the length and the average daily dose for chronic use of methadone on the quality of life.

\section{MATERIALS AND METHODS}

This study uses a prospective, observational, crosssectional questionnaire-based study method. The questionnaire used in the study is standardized and validated for use in the Bulgarian language: SF 36 v.2, quality of life, which assesses the quality of life in eight different components: physical functioning (PF), role-physical (RP), bodily pain (BP), general health (GH ), vitality (VT), social functioning (SF), role-emotional (RE), mental health $(\mathrm{MH})$. It provides a summarized evaluation both for physical (PCS) and mental components (MCS). ${ }^{14,15}$ The assessment of each component is on a scale of 0 to 100 , with scores of 100 indicating the best condition. The evaluation system is based upon a representative sample of the population and the questionnaire can be used to assess the physical and mental status of the participants in relation to the general population - norm-based scores (NBS).

The total number of participants was 100 people divided into two groups - 74 patients undergoing chronic treatment with methadone in the patients' group and 24 healthy volunteers in the control group. There were no significant differences in age and sex between the groups. A total of five methadone maintenance treatment programs with opiate agonists and agonists-antagonists at four big cities in Bulgaria - Sofia, Plovdiv, Pazardjik, Stara Zagora, were included in the study. Patient group was classified as three subgroups based on the mean and SD of the following three factors: dose, duration of treatment, and exposure to heroin before first methadone treatment. The low subgroup had one of the three factors below one $\mathrm{SD}$ of the mean (i.e., < mean- SD); medium subgroup had one of the three factors between one $\mathrm{SD}$ (i.e., mean $\pm \mathrm{SD}$ ); high subgroup had one of the three factors above one SD of the mean (i.e., $>$ mean+SD). The age range of the patients was between 18 and 40 years. Exclusion criteria were accompanying mental disorders and substance abuse in the past three months. Prevalence of HCV was taken in consideration as marking the status from medical documentation available in the methadone programs for each patient.

For the purposes of comparison analyses we used 24 healthy volunteers as a control group. Criteria for inclusion in the control group were no history of drug abuse and age range from 18 to 40 years. Exclusion criteria were accompanying physical or mental disorders. Control and patients' group were also matched by BMI and there was no difference between the groups by this criterion. Comparisons of survey results were performed between patients and healthy controls also between subgroups, divided by factors dose, duration of exposure to methadone and duration of exposure to heroin prior initiation of treatment of methadone in the patients' group. The survey form in Bulgarian language is officially translated and validated and the software for processing the results was presented courtesy of OptumTM, which possesses the right to distribute and license the survey. ${ }^{16}$

For statistical analyses we used SPSS Inc., IBM SPSS Statistics v. 21.0. The statistical methods used in the investigations were descriptive statistics, independent samples $t$-test, Fisher's exact test ANOVA, post-hoc analysis.

\section{RESULTS}

The mean daily dose of methadone used for maintenance treatment of the patients was $9.8( \pm 4.0) \mathrm{ml} /$ daily or $98 \mathrm{mg} /$ daily. The mean duration of treatment was $33.68( \pm 24.25)$ months and the mean duration of exposition to heroin before starting treatment with methadone was $6.54( \pm 3.4)$ years. Numbers of patients of the 3 subgroups by dose, duration of treatment and exposure to heroin before initiating treatment with methadone in patients' group are presented in Table 1.

The mean score of all the components of the survey is presented in Table 2.

Comparisons between the patients' group and control group showed that there were significant differences in all of the components of the survey 
$(\mathrm{P}<0.05)$. The patients group showed significantly lower results in all eight domains as well as the PCS and MCS (Fig. 1.)

In-group analyses in the patients' group were made by doing comparison analyses of the defined subgroups by dose, duration of treatment and exposure to heroin prior treatment. No significant differences were found in any of the components of the survey between the subgroups.

$51.32 \%$ of patients had a history of HCV. Compared by presence of HCV no significant differences were found by any of the domains of the survey between two groups.

\section{DISCUSSION}

This study evaluated the effect of MMT on patients from 5 programs in subjective function and well-being. The key results indicated that patients on MMT experienced a marked decrease in scores on all scales, as well as the PCS and MCS of the SF-36-survey. It must be taken in consideration that co-occurring psychiatric disorders are among the difficulties faced by patients with MMT and negatively impact quality of life. ${ }^{17}$ People undergoing chronic MMT are in a young age with much co-morbidity ${ }^{18}$ infected with $\mathrm{HBV}, \mathrm{HBC}, \mathrm{HIV}^{19}$. It is well-known

Table 1. Number of patients by subgroups in the patients' group defined by dose, duration of treatment and exposure to heroin before initiating treatment with methadone

\begin{tabular}{cccc}
\hline Subgroups & $\begin{array}{c}\text { Dose of methadone } \\
\text { /number of patients/ }\end{array}$ & $\begin{array}{c}\text { Duration of treatment } \\
\text { /number of patients/ }\end{array}$ & $\begin{array}{c}\text { Use of heroin before initiating } \\
\text { treatment with methadone } \\
\text { /number of patients/ }\end{array}$ \\
\hline $\begin{array}{c}\text { Low } \\
\text { Mean - SD } \\
\text { Medium } \\
\text { Mean } \pm \text { SD } \\
\text { High }\end{array}$ & 11 & 15 & 20 \\
$>$ Mean + SD & 55 & 49 & 34 \\
All & 10 & 12 & 22 \\
\hline
\end{tabular}

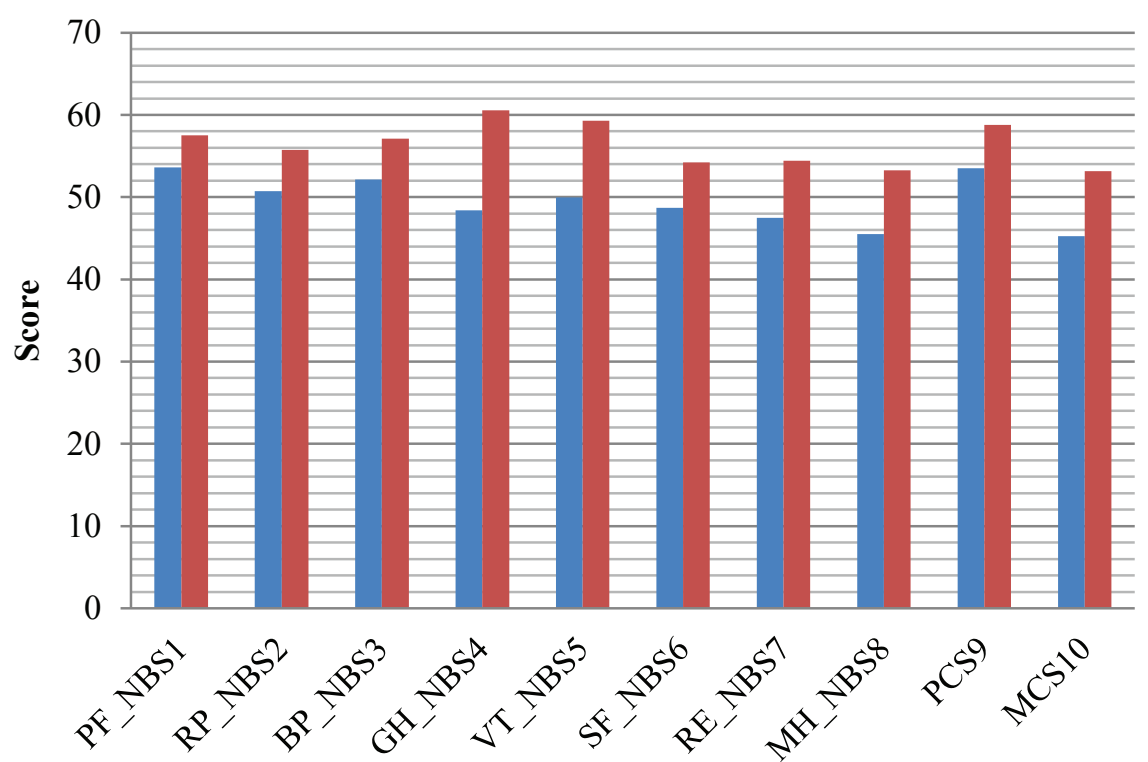

- Patients

- Controls

\section{Components of the Survey}

1. Physical Functioning norm-based scores

2. Role Physical norm-based scores

3. Bodily Pain norm-based scores

4. General Health norm-based scores

5. Vitality norm-based scores
6. Social Functioning norm-based scores

7. Role Emotional norm-based scores

8. Mental Health norm-based scores

9. Physical Component Score

10. Mental Component Score

Figure 1. Comparing results of the survey SF 36 v.2 between patients and controls 
Table 2. Number of participants and score of the components of the survey

\begin{tabular}{lcccc}
\hline & Participants & N & Mean & Std. Deviation \\
\hline PF_NBS & Patients & 76 & 53.61 & 4.24 \\
& Controls & 24 & 57.54 & 0.00 \\
RP_NBS ${ }^{2}$ & Patients & 76 & 50.72 & 8.56 \\
& Controls & 24 & 55.75 & 3.37 \\
BP_NBS & Patients & 76 & 52.12 & 10.51 \\
& Controls & 24 & 57.09 & 4.59 \\
GH_NBS & Patients & 76 & 48.37 & 9.38 \\
& Patients & 24 & 60.54 & 4.52 \\
VT_NBS & Patients & 76 & 49.98 & 9.62 \\
& Controls & 24 & 59.28 & 7.24 \\
SF_NBS & Patients & 76 & 48.70 & 10.28 \\
& Controls & 24 & 54.21 & 6.58 \\
RE_NBS $^{7}$ & Patients & 76 & 47.46 & 10.64 \\
& Controls & 24 & 54.42 & 4.48 \\
MH_NBS & Patients & 76 & 45.53 & 9.53 \\
& Controls & 24 & 53.27 & 6.54 \\
PCS & Patients & 76 & 53.53 & 6.32 \\
& Controls & 24 & 58.76 & 2.10 \\
MCS $^{10}$ & Patients & 76 & 45.27 & 10.52 \\
\hline
\end{tabular}

1. Physical Functioning norm-based scores

2. Role Physical norm-based scores

3. Bodily Pain norm-based scores

4. General Health norm-based scores

5. Vitality norm-based scores

that the majority of patients undergoing chronic MMT experience problems with erectile function, endocrine disturbances and reproduction difficulties. ${ }^{20-22}$ In the attempt to solve problems of the opiate abusers multidisciplinary approach should be used which is a guarantee of success and the key to improving the quality of life of target population.

\section{CONCLUSIONS}

1. Opiate dependency has a negative influence on the quality of life of the affected persons.

2. Dose, duration of treatment with methadone and period of exposure to heroin prior initiating treatment did not show impact and influence if the results of the survey for quality of life.

3. The presence of HCV as a co-morbidity in patients undergoing treatment for opiate dependency
6. Social Functioning norm-based scores

7. Role Emotional norm-based scores

8. Mental Health norm-based scores

9. Physical Component Score

10. Mental Component Score

did not affect the quality of life.

An interesting phenomenon has been found in score of PF scale in controls group. The score of PF_NBS was 57.54 which is equal to score 100 of PF scale with $0.0 \mathrm{SD}$. The content of the 10-item PF scale reflects the importance of distinct aspects of physical functioning and the necessity of sampling a range of severe and minor physical limitations. Items represent levels and kinds of limitations between the extremes of physical activities. The PF items capture both the presence and extent of physical limitations using a three-level response continuum. Low scores indicate significant limitations in performing physical activities while high scores reflect little or no such limitations. Our study showed a decrease in the quality of life of Bulgarian methadone-treated patients compared with Control group and popula- 
tion norms. The results showed that treatment had a particularly serious negative impact on all of the components of the survey and no negative influence of HCV presence. The findings indicate a need for updated counselling and educational materials designed to provide adequate and consistent healthcare service to this patient setting. Active assessment and timely healthcare interventions could improve the standard consultation programs as well as patient's quality of life.

\section{REFERENCES}

1. Stewart BL. Methadone-Drug Interactions. Pain Treatment Topics 2006 January.

2. Herman J, Sharon S, John L. Methadone Maintenance Treatment (MMT): A Review of Historical and Clinical Issues. Mt Sinai J Med 2000;67(5-6):347-64.

3. Analysis of the Center for the Study of Democracy: "Organised crime in Bulgaria: Markets and trends. Available at http://www.csd.bg/artShowbg. php?id=9130 (Bulgarian).

4. Republic of Bulgaria National Drug control Strategy 2014-2018. Available at http://www.drugsinfo-bg. org/uploads/files/Strategy_2014-2018-1.pdf (Bulgarian).

5. National Programme for development of health care system for Methadone Maintenance Treatment in Bulgaria. Available at: www.ncn-bg.org (Bulgarian).

6. General Accounting Office. Methadone Maintenance: Some treatment programs are not effective; Greater federal oversight needed. $1990 \mathrm{GOA} / \mathrm{HRD}$ -90-104.

7. WHO. The Practices and context of Pharmacotherapy of opioid dependence in Central and Eastern Europe. 2004, WHO. Geneva.

8. Bell J, Hall W, Byth K. Changes in criminal activity after entering methadone maintenance. Brit J Addict 1992;87:251-8.

9. Marsch L. The efficacy of methadone maintenance interventions in reducing illicit opiate use, HIV risk behavior and criminality: a meta-analysis. Addiction 1998;93:515-532.

10. Wang PW, Lin HC, Yen CN, et all. Comparison of outcomes after 3-month methadone maintenance treatment between heroin users with and without HIV infection: a 3-month follow-up study. Harm Reduct J 2015;12:13.

11. Lin CY, Chang KC, Wang JD, Lee LJ. Quality of life and its determinants of heroin addicts receiving methadone maintenance program: comparison with matched referents from general population. J Formos Med Assoc 2015;27. pii: S0929-6646(15)00244-2. [Epub ahead of print]

12. Chang KC, Lin CY. Effects of publicly-funded and quality of life on attendance rate among methadone maintenance treatment patients in Taiwan: an 18-month follow-up study. Harm Reduc J 2015;12:40.

13. Hellard M, Rolls DA, Sacks-Davis R, Robins G, Pattison P, Higgs P, Aitken C, McBryde E. The impact of injecting networks on hepatitis $\mathrm{C}$ transmission and treatment in people who inject drugs. Hepatology 2014;60(6):1861-70.

14. Ware J, Gandek B. Overview of the SF-36 Health Survey and the International Quality of Life Assessment (IQOLA) Project. J Clin Epidemiol. 1998;51(11):903-12.

15. Su CT, Ng HS, Yang AL, Lin CY. Psychometric evaluation of the Short Form 36 Health Survey (SF-36) and the World Health Organization Quality of Life Scale Brief Version (WHOQOL-BREF) for patients with schizophrenia. Psychol Assess 2014;26(3):980-9.

16. Available at www.qualitymetric.com/Portals/0/Uploads/Documents/Public/QM_Catalog_2011.pdf

17. Teoh Bing Fei J, Yee A, Habil MH. Psychiatric comorbidity among patients on methadone maintenance therapy and its influence on quality of life. Am J Addict 2016;25(1):49-55.

18. Nordmann S, Lions C, Vilotitch A, et all. A prospective, longitudinal study of sleep disturbance and comorbidity in opiate dependence (the ANRS Methaville study). Psychopharmacology (Berl) 2016;233(7):1203-13.

19. Alshomrani AT. Prevalence of human immunodeficiency virus, hepatitis $C$ virus, and hepatitis $B$ virus infection among heroin injectors in the central region of Saudi Arabia. Saudi Med J 2015;36(7):802-6.

20. Hallinan R, Byrne A, Agho K, McMahon C, Tynan $\mathrm{P}$, Attia J. Erectile dysfunction in men receiving methadone and buprenorphine maintenance treatment. J Sex Med 2008;5:684-692.

21. de la Rosa RE, Hennessey J. Hypogonadism and methadone: hypothalamic hypogonadism after longterm use of high-dose methadone. Endocr Pract 1996;2:4-7.

22. Cicero TJ. Opiate and opioid modulation of reproductive endocrinology in the male and female: development and pregestational aspects. NIDA Res Monogr 1984;55:14-23. 


\title{
Хроническое лечение опиоидными агонистами в Болгарии - оценка качества жизни с помощью метода исследования SF 36 v.2
}

\author{
Сава В. Петров ${ }^{1}$, Мария М. Орбецова ${ }^{1}$, Янко Т. Илиев ${ }^{2}$, Дойчин Т. Бояджиев ${ }^{3}$ \\ 1 Вторая кафедра внутренних болезней, Отделение эндокринологии и метаболитных заболеваний, Факультет медици- \\ ны, Медицинский университет, Пловдив, Пловдив, Болгария \\ 2 Кафедра фармакологии и токсикологии лекарственных средств, Фармацевтический факультет, Медицинский универ- \\ ситет, Пловдив, Пловдив, Болгария \\ ${ }^{3}$ Кафедра прикладной математики, Пловдивский университет, Пловдив, Болгария
}

\section{Для корреспонденции: Сава Петров, Вторая кафедра внутренних болезней, Отделение эндокринологии и метаболитных заболеваний, Факультет медицины, Медицинский университет, Пловдив, Пловдив, Болгария, бул. Васила Априлова № 15A, 4002 Пловдив, Болгария. E-mail: Isava86@abv.bg Тел.: +359878987123}

Дата получения: 17 ноября 2015 г.

Дата приемки: 01 июня 2016 г. Дата публикации: 30 июня 2016 г.

Ключевые слова: метадон, качество жизни, опиаты, зависимость

Цитаты: Петров СВ, Орбецова ММ, Илиев ИТ, Бояджиев ДТ. Хроническое лечение опиоидными агонистами в Болгарии - оценка качества жизни с помощью метода исследования SF 36 v.2.

Folia Medica 2016;58(2);115-121, doi: 10.1515/folmed-2016-0019
Введение: Зависимость от психоактивных медикаментозных препаратов представляет собой расстройство с комплексным биопсихосоциальным генезисом, отличающееся хронически рецидивирующим течением заболевания. Зависимость от медикаментов причиняет многостороннее нарушение нормального функционирования человека и нуждается в подходе с разнообразной направленностью в процессе лечения.

Цель: Целью исследования является оценка качества жизни пациентов, подверженных хроническому лечению опиоидным агонистом метадоном, путем применения метода стандартизированной анкеты на болгарском языке.

Материалы и методы: В исследовании приняли участие пациенты в возрасте от 18 до 40 лет, подверженные хроническому лечению метадоном в течение не менее шести месяцев. В исследование было включено 100 участников - 76 пациентов по 5 клиническим программам в Болгарии, а 24 клинически здоровых участника той же возрастной группы и без прошлых данных о злоупотреблении психотропными препаратами, о наличии психиатрических и соматических заболеваний были выбраны в качестве контрольной группы.

Результаты: Были выявлены существенные различия между пациентами и участниками в составе контрольной группы по всем компонентам исследования $(\mathrm{P}<0,05)$. У пациентов были установлены более низкие результаты по сравнению с контрольной группой при SF-36 по восьми компонентам - и в плане физического, так и ментального компонента при обобщении SF-36-исследования. При сравнении результатов у пациентов из разных групп с точки зрения дозы, продолжительности лечения метадоном и периода злоупотребления героином до начала лечения не было выявлено существенных различий. Нет существенных различий между пациентами, являющимися и не являющимися носителями вируса гепатита $C$.

Заключение: Зависимость от опиатов представляет собой состояние, связанное с более низким качеством жизни. Продолжительность лечения, доза метадона, период злоупотребления героином до начала лечения и заболевания, вызванного вирусом гепатита C, не коррелируют с более низкими результатами. 